\title{
ВПЛИВ ГІПОТИРЕОЗУ НА ДИНАМІКУ МЕТАБОЛІЧНОГО І ГОРМОНАЛЬНОГО СТАТУСУ В ЧОЛОВІКІВ
}

๑Н. В. Пасєчко, Л. В. Наумова, Т. І. Крицький, Н. І. Ярема, І. П. Савченко, А. О. Боб, І. В. Смачило, Л. В. Радецька, М. Є. Гаврилюк, А. І. Хоміцька, О. О. Чукур

Тернопільский начіональний медичний університет імені І. Я. Горбачевського МОз України

РЕЗЮМЕ. Порушення в ендокринній системі у чоловіків з гіпотиреозом сприяють розвитку гіпогонадизму і послабленню фертильності внаслідок очевидного зв'язку репродуктивних гормонів і сперматогенезу.

Мета дослідження - оцінити гормональний статус, метаболічні й антропометричні показники у чоловіків активного репродуктивного віку з первинним гіпотиреозом.

Матеріал і методи. Проведено порівняльний аналіз гормональних, антропометричних і метаболічних показників 60 чоловіків з гіпотиреозом і 25 чоловіків без гіпотиреозу (контрольна група).

Результати. Встановлено, що для групи чоловіків з гіпотиреозом, порівняно з контрольною групою, характернішими були підвищення загального холестерину та ліпопротеїдів низької щільності, а також зниження рівня тестостерону та підвищення фолікулостимулювального гормону, тоді як рівень інших репродуктивних гормонів, таких як естрадіол та лютеїнізуючий гормон, не змінювався. Вважають, що у чоловіків, хворих на гіпотиреоз, зниження рівня тестостерону та підвищення фолікулостимулювального гормону $\epsilon$ первинними індикаторами, які свідчать про розвиток функціонального гіпогонадизму, що призводить до зниження лібідо, еректильної дисфункції та субфертильності.

Висновки. У чоловіків з гіпотиреозом виявлено зниження вмісту тестостерону і підвищення рівня фолікулостимулювального гормону в крові на 63 \%, порівняно з контрольною групою. У 97 \% чоловіків з гіпотиреозом спостерігали підвищення в крові вмісту загального холестерину і холестерину ліпопротеїнів низької щільності.

КЛючОВІ СЛОВА: гіпотиреоз; репродуктивні гормони; метаболічний статус; фолікулостимулювальний гормон; лютеїнізуючий гормон.

Вступ. Гіпотиреоз негативно відображається на самопочутті, активності і репродуктивному статусі як жінок, так і чоловіків [1, 2]. Він часто супроводжується дисліпідемією, артеріальною гіпертензією, серцево-судинними захворюваннями, цукровим діабетом 2-го типу, остеоартритом, зниженням фертильності й іншими станами [3]. Негативний вплив гіпотиреозу на репродуктивну функцію чоловіків заслуговує на особливу увагу. Інтерес до цієї проблеми постійно зростає, адже, крім іншого, такий зв'язок може бути однією з причин чоловічого безпліддя. Відомо про широкий спектр впливу гіпотиреозу на фертильність [4].

Вивчені декілька шляхів, які пов'язують метаболічні порушення у чоловіків, хворих на гіпотиреоз, зі змінами найважливіших потенційних маркерів чоловічої фертильності, зокрема параметрами спермограми або профілю репродуктивних гормонів $[5,6]$. Дослідження останніх років чітко показують вплив гіпотиреозу на профіль репродуктивних гормонів у чоловіків, який насамперед характеризується зниженням рівня тестостерону і сексзв'язувального глобуліну в периферійній крові [7].

Порушення в ендокринній системі чоловіків з гіпотиреозом сприяють розвитку гіпогонадизму i послабленню фертильності внаслідок очевидного зв'язку репродуктивних гормонів і сперматогенезу [8].
Проте досі окремі аспекти взаємозв'язку гіпотиреозу, гормонального статусу і гіпогонадизму у чоловіків залишаються практично не вивченими. Можна згадати популяційну роботу, яка показує чіткий зворотний зв'язок між рівнем тестостерону в крові і компонентами метаболічного синдрому у чоловіків [9].

Тому важливо встановити, чи супроводжується гіпотиреоз андрогенним дефіцитом і змінами функціональної активності системи гіпофіз гонади, які $\epsilon$ чинниками ризику гіпогонадизму i субфертильності у чоловіків.

Мета дослідження - оцінити гормональний статус, метаболічні й антропометричні показники у чоловіків активного репродуктивного віку 3 первинним гіпотиреозом.

Матеріал і методи дослідження. Проведено порівняльний аналіз гормональних, антропометричних і метаболічних показників 60 чоловіків з гіпотиреозом (основна група) і 25 чоловіків без гіпотиреозу й інших хронічних соматичних захворювань (контрольна група). Середній вік обстежених складав $(42,4 \pm 2,7)$ року. Усі чоловіки підписали інформовану згоду на участь у дослідженні.

У всіх обстежених осіб проводили забір периферійної крові в ранкові години натще. У сироватці крові визначали рівень тиреотропного гормону (ТTГ), тестостерону, естрадіолу, лютеїнізуючого 
Огляди літератури, оригінальні дослідження, погляд на проблему, випадок з практики, короткі повідомлення гормону (ЛГ), фолікулостимулювального гормону (ФСГ) і кортизолу імуноферментним методом. У тих же зразках мікрометодом імуноферментного аналізу визначали загальний холестерин (ЗХС), тригліцериди (ТГ), холестерин ліпопротеїнів високої щільності (ХС лПВЩ). Вміст холестерину ліпопротеїнів низької щільності (ХС ЛПнЩ) визначали розрахунковим шляхом, використовуючи формулу Фрідевальда.

Статистичну обробку даних проводили з використанням пакета комп'ютерних програм Statistica 6.0. Використовували однофакторний дисперсійний аналіз. Критичний рівень значущості при перевірці статистичних гіпотез приймали за 0,05.

Результати й обговорення. Антропометричні, гормональні й метаболічні показники у чоловіків з гіпотиреозом представлені в таблиці 1.

Таблиця 1. Антропометричні, гормональні й метаболічні показники у чоловіків, хворих на гіпотиреоз

\begin{tabular}{|c|c|c|}
\hline Параметри & Гіпотиреоз, n=60 & Контроль, $\mathrm{n}=25$ \\
\hline Вік, роки & $42,4 \pm 2,7$ & $39,8 \pm 1,7$ \\
\hline $\mathrm{IMT}, \mathrm{kr} / \mathrm{M}^{2}$ & $28,3 \pm 0,8^{*}$ & $23,7 \pm 0,6$ \\
\hline ЛГ, мМО/мл & $3,67 \pm 0,22$ & $3,68 \pm 0,28$ \\
\hline ФСГ, мМО/мл & $6,31 \pm 0,89 *$ & $4,16 \pm 0,38$ \\
\hline Тестостерон, нмоль/л & $19,02 \pm 1,14^{*}$ & $25,83 \pm 1,27$ \\
\hline Естрадіол, нмоль/л & $0,165 \pm 0,08$ & $0,179 \pm 0,08$ \\
\hline Кортизол, нмоль/л & $419,64 \pm 31,07$ & $472,11 \pm 26,87$ \\
\hline ТТГ, мкМО/мл & $7,08 \pm 0,18^{*}$ & $1,86 \pm 0,14$ \\
\hline ЗХС, ммоль/л & $5,34 \pm 0,16^{*}$ & $4,57 \pm 0,11$ \\
\hline ТГ, ммоль/л & $0,86 \pm 0,08$ & $0,76 \pm 0,06$ \\
\hline ХС ЛПВЩ, ммоль/л & $1,47 \pm 0,07$ & $1,52 \pm 0,08$ \\
\hline ХС лПНЩ, ммоль/л & $3,21 \pm 0,16^{*}$ & $2,39 \pm 0,14$ \\
\hline
\end{tabular}

Примітка. * - достовірність відмінностей з контрольною групою (ІМТ - індекс маси тіла; ФСГ - фолікулостимулювальний гормон; ЛГ - лютеїнізуючий гормон, ТТГ - тиреотропний гормон; ХС ЛПВЩ - холестерин ліпопротеїнів високої щільності; ХС ЛПНЩ холестерин ліпопротеїнів низької щільності).

Чоловіки обох досліджуваних груп не відрізнялися за віком, однак за показником індексу маси тіла (IMT) мали відмінності, які в осіб з гіпотиреозом були достовірно вищі, порівняно 3 контролем. При цьому середнє значення IMT у групі чоловіків з гіпотиреозом не потрапляло в діапазон значень, встановлених для ожиріння. Вміст ХС ЛПВП у крові чоловіків обох груп був у межах норми і не відрізнявся між групами, однак у осіб з гіпотиреозом, порівняно з контролем, були достовірно збільшені рівні ЗХС і ХС лПНЩ.

У чоловіків з гіпотиреозом рівень тестостерону в крові виявився достовірно нижчим, ніж у чоловіків контрольної групи, при цьому він не досягав нижньої межі нормальних значень (12 нмоль/л) i, отже, андрогенний дефіцит був виражений відносно помірно.

Результати дослідження вказують на достовірне підвищення рівня ФСГ у чоловіків, хворих на гіпотиреоз, порівняно з контрольною групою, а вміст ЛГ, естрадіолу і кортизолу у них не відрізнявся від аналогічних показників контрольної групи.

3 огляду на те, що система гіпофіз - гонади тісно взаємодіє із гіпофізарно-тиреоїдною і гіпофізарно-адреналовою системами, у чоловіків 3 гіпотиреозом вивчали вміст кортизолу, у резуль- таті якого достовірних відмінностей цього показника у всіх обстежених не виявлено. Отже, функціональні резерви і компенсаторні механізми ендокринної системи у чоловіків з гіпотиреозом практично повністю збережені.

Результати й обговорення. Відомо, що ЩЗ, как орган внутрішньої секреції, бере участь у регуляції репродуктивної функції. Гіпогонадизм при гіпотиреозі також може бути обумовлений підвищеною ароматизацією андрогенів в естрогени жировою тканиною і зменшенням співвідношення тестостерон/естрадіол, що призводить до пригнічення секреції ЛГ гіпофізом і зниження продукції тестостерону статевими залозами [10].

У проведеному нами дослідженні не виявлено зниження рівня лГ у чоловіків з гіпотиреозом, хоча такий феномен виявлено в осіб з ожирінням [11]. 3 іншого боку, надмірна продукція лептину адипоцитами при гіпотиреозі може призвести до вторинного гіпогонадизму через безпосереднє пригнічення синтезу тестостерону клітинами Лейдіга [12].

У нашій роботі виявлено достовірне збільшення рівня ФСГ у групі чоловіків з гіпотиреозом, порівняно з контролем. Оскільки ФСГ необхідний для нормального сперматогенезу, збільшення 
Огляди літератури, оригінальні дослідження, поглядн на його рівня в крові у чоловіків з гіпотиреозом свідчить про послаблення функції сім'яників і компенсаторне підвищення гіпофізарної активності за принципом негативного зворотного зв'язку для відновлення гомеостазу [13].

Отримані результати, як і дані літератури [14, 15], переконливо свідчать про зв'язок гіпотиреозу зі змінами в гормональному балансі у чоловіків, які є чинником ризику гіпогонадизму, зниженої сексуальності і ослабленого сперматогенезу. Зважаючи на значну поширеність гіпотиреозу, поєднання гіпогонадизму, сексуальної дисфункції і олігоспермії можуть призводити до послаблення чоловічої фертильності на популяційному рівні.

Висновки. У чоловіків з гіпотиреозом виявлено зниження вмісту тестостерону і підвищення рівня фолікулостимулювального гормону в крові, що на $63 \%$ більше, ніж у контрольній групі.

У 97 \% чоловіків з гіпотиреозом спостерігали підвищення в крові вмісту загального холестерину і холестерину ліпопротеїнів низької щільності.

Доведено, що наявність гіпотиреозу в чоловіків не впливає на рівень інших гормонів у крові, а саме лютеїнізуючого, естрадіолу та кортизолу.

\section{ЛІТЕРАТУРА}

1. Wagner M. S. The role of thyroid hormone in testicular development and function / M. S. Wagner, S. M. Wajner, A. L. Maia // J. Endocrinol. - 2008. - No. 199. - P. 351365. DOI: $10.1677 / J O E-08-0218$

2. Krassas G. E. Thyroid function and human reproductive health / G. E. Krassas, K. Poppe, D. Glinoer // Endocr. Rev. - 2010. - No. 31. - P. 702-755. DOI: 10.1210/ ег.2009-0041

3. Voloshyna L. Hypothyroidism - a special comorbidity factor in patients with osteoarthrosis: clinical, pathophysiological and prognostic aspects / L. Voloshyna, O. Doholich, I. Sithinska // Georgian Med. News. - 2017. No. (272). - P. 53-59.

4. Prevalence of hypothyroidism in infertile women and evaluation of response of treatment for hypothyroidism on infertility / I. Verma, R. Sood, S. Juneja, S. Kaur // International Journal of Applied and Basic Medical Research. - 2012. - No. 2 (1). - P. 17-19. DOI: 10.4103/2229-516x.96795.

5. Krajewska-Kulak E. Thyroid function in male infertility / E. Krajewska-Kulak, P. Sengupta // Front Endocrinol. (Lausanne). - 2013. - No. 4. - P. 174. DOI: 10.3389/ fendo.2013.00174

6. Hypothyroidism has an adverse effect on human spermatogenesis: A prospective, controlled study/G. E. Krassas, F. Papadopoulou, K. Tziomalos [et al.] // Thyroid. - 2008. - No. 18. - P. 1255-1259. DOI: 10.1089/thy.2008.0257

7. Singh R. Thyroid hormones in male reproduction and fertility / R. Singh, A. J. Hamadaa, A. Agarwal // Open Reprod. Sci. J. - 2011. - No. 3. - P. 98-104. DOI:10.2174/ 1874255601103010098

8. Ajayi A. F. Hypothalamic-pituitary-ovarian axis in

thyroid dysfunction / A. F. Ajayi, R. E. Akhigbe, L. O. Ajayi // West Indian Med. J. - 2013. - No. 62. - P. 835-838. DOI: $10.7727 /$ wimj.2013.038

9. Is overweight a risk factor for reduced semen quality and altered serum sex hormone profile? / A. S. Aggerholm, A.M. Thulstrup, G. Toft [et al.] // Fertil. Steril. 2008. - No. 90. - P. 619-626.

10. Rambhatla $A$. The role of estrogen modulators in male hypogonadism and infertility / A. Rambhatla, J. N. Mills, J. Rajfer // Rev. Urol. - 2016. - No. 18 (2). - P. 66-72. DOI: 10.3909/riu0711

11. Body mass index in relation to semen quality and reproductive hormones among 1,558 Danish men / T. K. Jensen, A. M. Andersson, N. Jørgensen [et al.] // Fertil. Steril. 2004. - No. 82. - P. 863-870.

12. Serum testosterone levels in male hypogonadism: Why and when to check - A review / M. Livingston, A. Kalansooriya, A. J. Hartland [et al.] // Int. J. Clin. Pract. 2017. - No. 71 (11). - P. e12995. DOI: 10.1111/ijcp.12995

13. Role of FSH in the regulation of spermatogenesis: clinical aspects / E. Nieschlag, M. Simoni, J. Gromoll, G. F. Weinbauer // Clin. Endocrinol. - 1999. - No. 51. P. 139-146.

14. British Society of Sexual Medicine. Guidelines of the management of sexual problems in men: the role of androgens. - 2010. - No. 1-12. URL : https://www.endocrinology.org/media/1454/10-12-01_uk-guidelines-androgens-male.pdf. Accessed June 21, 2017.

15. EMAS Study Group. Late-onset hypogonadism and mortality in aging men / S. R. Pye, J. D. Huhtaniemi, D. M. Finn [et al.] // J. Clin. Endocrinol. Metabol. - 2014. No. 99. - P. 1357-1366.

\section{REFERENCES}

1. Wagner, M.S., Wajner, S.M., \& Maia, A.L. (2008). The role of thyroid hormone in testicular development and function. J. Endocrinol., 199, 351-365. doi: 10.1677/JOE08-0218.

2. Krassas, G.E., Poppe, K., \& Glinoer, D. (2010). Thyroid function and human reproductive health. Endocr Rev., 31, 702-755. doi: 10.1210/ег.2009-0041.

3. Voloshyna, L., Doholich, O., \& Sithinska, I. (2017). Hypothyroidism - a special comorbidity factor in patients with osteoarthrosis: clinical, pathophysiological and prognostic aspects. Georgian Med. News, (272), 53-59.

4. Verma, I., Sood, R., Juneja, S., \& Kaur, S. (2012). Prevalence of hypothyroidism in infertile women and evaluation of response of treatment for hypothyroidism 
Огляди літератури, оригінальні дослідження, погляд на проблему, випадок з практики, короткі повідомлення on infertility. International Journal of Applied and Basic Medical Research, 2 (1), 17-19. doi: 10.4103/2229$516 \times .96795$.

5. Krajewska-Kulak, E., \& Sengupta, P. (2013). Thyroid function in male infertility. Front Endocrinol. (Lausanne), 4, 174. doi:10.3389/fendo.2013.00174.

6. Krassas, G.E., Papadopoulou, F., Tziomalos, K., Zeginiadou, T., \& Pontikides, N. (2008). Hypothyroidism has an adverse effect on human spermatogenesis: A prospective, controlled study. Thyroid, 18, 1255-1259. doi: 10.1089/ thy.2008.0257.

7. Singh, R., Hamadaa, A.J., \& Agarwal, A. (2011). Thyroid hormones in male reproduction and fertility. Open Reprod. Sci. J., 3, 98-104. doi:10.2174/1874255601103010098.

8. Ajayi, A.F., Akhigbe, R.E., \& Ajayi, L.O. (2013). Hypothalamic-pituitary-ovarian axis in thyroid dysfunction. West Indian Med. J., 62, 835-838. doi: 10.7727/wimj.2013.038.

9. Aggerholm, A.S., Thulstrup, A.M., Toft, G., RamlauHansen, C.H., \& Bonde, J.P. (2008). Is overweight a risk factor for reduced semen quality and altered serum sex hormone profile? Fertil. Steril., 90, 619-626.

10. Rambhatla, A., Mills, J.N., \& Rajfer, J. (2016). The role of estrogen modulators in male hypogonadism and

infertility. Rev. Urol., 18 (2), 66-72. doi: 10.3909/riu0711.

11. Jensen, T.K., Andersson, A.M., Jørgensen, N., Andersen, A.G., Carlsen, E., Petersen, J.H., \& Skakkebaek, N.E. (2004). Body mass index in relation to semen quality and reproductive hormones among 1,558 Danish men. Fertil. Steril., 82, 863-870.

12. Livingston, M., Kalansooriya, A., Hartland, A.J., Ramachandran, S., \& Heald, A. (2017). Serum testosterone levels in male hypogonadism: Why and when to check - A review. Int. J. Clin. Pract., 71 (11), e12995. doi: 10.1111/ ijcp.12995.

13. Nieschlag, E., Simoni, M., Gromoll, J., \& Weinbauer, G.F. (1999). Role of FSH in the regulation of spermatogenesis: clinical aspects. Clin. Endocrinol., 51, 139-146.

14. British Society of Sexual Medicine. (2010). Guidelines of the management of sexual problems in men: the role of androgens, 1-12. Retrieved from: https://www. endocrinology.org/media/1454/10-12-01_uk-guidelinesandrogens-male.pdf.

15. Pye, S.R., Huhtaniemi, J.D., Finn, D.M., Lee, D.M., O'Neill, T.W., Tajar, A., ... \& Wu, F.C. (2014). EMAS Study Group. Late-onset hypogonadism and mortality in aging men. J. Clin. Endocrinol. Metabol., 99, 1357-1366.

\title{
ВЛИЯНИЕ ГИПОТИРЕОЗА НА ДИНАМИКУ МЕТАБОЛИЧЕСКОГО И ГОРМОНАЛЬНОГО СТАТУСА МУЖЧИН
}

\author{
๑Н. В. Пасечко, Л. В. Наумова, Т. И. Крицкий, Н. И. Ярема, И. П. Савченко, А. О. Боб, \\ И. В. Смачило, Л. В. Радецкая, М. Е. Гаврилюк, А. И. Хомицкая, О. О. Чукур
}

Тернопольский национальный медицинский университет имени И. Я. Горбачевского моз Украины

РЕзЮМЕ. Нарушения В эндокринной системе мужчин с гипотиреозом способствуют развитию гипогонадизма и снижению фертильности в связи с очевидной связью репродуктивних гормонов и сперматогенеза.

Цель исследования - оценка гормональных, метаболических и антропометрических показателей у мужчин репродуктивного возраста с первичным гипотиреозом.

Материал и методы. Проведен сравнительный анализ гормональных, антропометрических и метаболических показателей 60 мужчин с гипотиреозом и 25 мужчин без гипотиреоза (контрольная группа).

Результаты. Установлено, что группа мужчин с гипотиреозом, по сравнению с контрольной группой, характеризовалась повышенными уровнями общего холестерина и холестерина липопротеинов низкой плотности. В группе мужчин с гипотиреозом наблюдалось снижение уровня тестостерона и повышение уровня фолликулостимулирующего гормона (ФСГ) в крови, по сравнению с контролем, в то время как уровень других репродуктивных гормонов (эстрадиола, лютеинизирующего гормона) не менялся. Предполагается, что у мужчин с гипотиреозом сниженный уровень тестостерона и повышенный уровень ФСГ являются первыми индикатороми риска развития функционального гипогонадизма, что может приводить впоследствии к снижению либидо, эректильной дисфункции и субфертильности.

Выводы. У мужчин с гипотиреозом обнаружено снижение содержания тестостерона и повышение уровня фолликулостимулирующего гормона в крови, что на 63 \% больше, нежели у мужчин контрольной группы. У $97 \%$ мужчин с гипотиреозом наблюдалось повышение в крови общего холестерина и липопротеидов низкой плотности.

КЛЮЧЕВЫЕ СЛОВА: гипотиреоз; репродУктивные гормоны; метаболический статус; фолликулостимулирующий гормон; лютеинизирующий гормон. 
@N. V. Pasechko, L. V. Naumova, T. I. Krytskyy, N. I. Yarema, I. P. Savchenko, A. O. Bob, I. V. Smachylo, L. V. Radetska, M. Y. Havryliuk, A. I. Khomitska, O. O. Chukur

\section{Horbachevsky Ternopil National Medical University}

SUMMARY. Violations in the endocrine system of men with hypothyroidism contribute to the development of hypogonadism and the weakening of fertility due to the apparent linkage of reproductive hormones and spermatogenesis.

The aim of this study was to assess the hormonal status, metabolic and anthropometric indexes in men of active reproductive age with primary hypothyroidism.

Material and Methods. A comparative analysis of hormonal, anthropometric and metabolic parameters in 60 men with hypothyroidism and 25 men without hypothyroidism (control group) was conducted.

Results. It was found that for the group of men with hypothyroidism, in comparison with the control group, more common were increase in total cholesterol and low density lipoprotein, as well as a decrease in testosterone levels and an increase in follicle-stimulating hormone, while other reproductive hormones such as estradiol and luteinizing hormones were not changed. It is believed that in men suffering from hypothyroidism, lowering the testosterone level and increasing the follicle stimulating hormone is the primary index which indicates the development of functional hypogonadism, which ultimately leads to a decrease in libido, erectile dysfunction and subfertility.

Conclusions. Men with hypothyroidism were shown to lower testosterone levels and increase the level of follicle stimulating hormone in the blood, which is $63 \%$ higher than in the control group. In $97 \%$ of men with hypothyroidism, there was an increase in blood levels of total cholesterol and cholesterol of low density lipoproteins.

KEY WORDS: hypothyroidism; reproductive hormones; testosterone; metabolic status; follicle stimulating hormone; luteinizing hormone. 